\title{
SOME CLINICAL AND EPIDEMIOLOGICAL FEATURES OF INFLUENZA-ASSOCIATED PNEUMONIA DEPENDING ON THE ETIOLOGICAL AGENT
}

DOI: 10.36740/WLek202007119

\author{
Vadym A. Bodnar, Tetiana I. Koval, Nataliia 0. Pryimenko, Galyna M. Dubyns'ka, Tetiana M. Kotelevska, \\ Nina P. Lymarenko, Liudmyla M. Syzova, Lesia A. Bodnar \\ UKRAINIAN MEDICAL STOMATOLOGICAL ACADEMY, POLTAVA, UKRAINE
}

\begin{abstract}
The aim: To analyze the epidemiological data and clinical course of pneumonia as a complication of influenza in the Poltava region, depending on the etiological agent. Materials and methods: We have analysed the data of the official reporting documentation provided by the State Institution "Poltava Regional Laboratory Center of the Ministry of Health of Ukraine" and the chart of patients with a laboratory confirmed diagnosis of influenza who were in inpatient treatment at the Poltava Regional Clinical Infectious Hospital (PRCIH) in 2016-2018 years. In more detail, we examined 95 patients with pneumonia, which complicated the course of the flu. There were 43 (45.26\%) female patients, -52 (54.74\%) male patients, aged 18 to 80 years.

Results: Studies have shown that despite a decrease in the incidence of influenza in recent years, the incidence of pneumonia, which complicated the course of the flu, remained consistently high (19.7\% - 20.8\%) with bacteriological isolation of S.pneumoniae (22.11\%), S.aureus (13.68\%), Haemophilus influenza (4.21\%) and E.coli (3.16\%). Severe course of pneumonia with bloody sputum, evident shortness of breath, bilateral lung damage, and need for oxygen support were significantly more frequently reported in patients with isolated S.pneumoniae and S.aureus. However, the severe course of the disease with the formation of abscesses in the lungs was observed only in the group $S$. aureus despite the relatively young age of such patients and significantly fewer risk factors for severe influenza and comorbidities.

Conclusions: The study showed a consistently high incidence of pneumonia, which complicated the flu and caused by S.pneumoniae, S.aureus, Haemophilus influenza and E.coli. Pneumonia caused by S.pneumoniae and S.aureus, were characterized the most severe course; however, a severe course with the formation of abscesses in the lung tissue was observed only in the group of S.aureus.
\end{abstract}

KEY WORDS: influenza-associated pneumonia, etiological structure, risk factors, clinical features

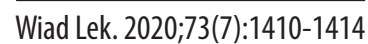

\section{INTRODUCTION}

Influenza is the most common and widespread infectious disease on the globe. Thus, according to estimates, influenza and acute respiratory diseases (ARD) annually affects from 4 to $15 \%$ of the world's population, and $250-450$ thousand people die from influenza and its complications [1]. Incidence of disease increases to $50-70 \%$ during the influenza pandemics, which are associated with genetic shift in the pathogen in the human population. Moreover, mortality from influenza and its complications ranks first among all infectious diseases $[2,3,4,5]$

Pneumonia remains the main cause of morbidity, hospitalization and mortality in an influenza, and therefore it is a very complicated health problem worldwide, including developed countries. It is known that the influenza is complicated with pneumonia in $10-20 \%$ of all patients with influenza, and in about half of the hospitalized patients [6, 7]. According to present knowledge, there is a tendency for a severe course of community-acquired pneumonia (CAP) that occurs with influenza [2]. Often such pneumonia is characterized by severe intoxication syndrome, hemodynamic disorders, severe respiratory failure with the development of acute respiratory distress syndrome (ARDS).
In recent years, reports in the scientific literature indicate that the etiology of pneumonia has expanded significantly, and among the agents that can cause severe pneumonia, there may be various associations of influenza virus with bacteria [4].

At the same time, only some reports describe the dependence of the severity of pneumonia on the etiological factor and attempt to distinguish the characteristic clinical features of pneumonia caused by a particular pathogen or a combination thereof.

Thus, the problem of influenza-associated pneumonia is topical, which makes the need for further study of the features of their clinical course, generalization of the results of laboratory and instrumental and radiological studies to optimize diagnostic and therapeutic tactics taking into account the etiological structure.

\section{THE AIM}

To analyze the epidemiological data and clinical course of pneumonia as a complication of influenza in the Poltava region, depending on the etiological factor. 


\section{MATERIALS AND METHODS}

To achieve this aim we have analysed the data of the official reporting documentation provided by the State Institution "Poltava Regional Laboratory Center of the Ministry of Health of Ukraine" and the chart of patients with a laboratory confirmed diagnosis of influenza who were in inpatient treatment at the Poltava Regional Clinical Infectious Hospital (PRCIH) in 2016-2018. In more detail, we examined 95 patients with pneumonia, which complicated the course of the flu. There were 43 (45.26\%) female patients, $-52(54.74 \%)$ male patients, aged 18 to 80 years.

Influenza was diagnosed based on epidemiological, clinical data, serological findings with the determination of the increasing of specific antibody titers in the hemagglutination inhibition reaction with influenza diagnostic agent $\mathrm{A} / \mathrm{H} 1 \mathrm{~N} 1, \mathrm{~A} / \mathrm{H} 2 \mathrm{~N} 2, \mathrm{~A} / \mathrm{H} 3 \mathrm{~N} 2, \mathrm{~B}$ and the detection of Influenza virus $\mathrm{A} / \mathrm{H} 1 \mathrm{~N} 1, \mathrm{~A} / \mathrm{H} 2 \mathrm{~N} 2, \mathrm{~A} / \mathrm{H} 3 \mathrm{~N} 2$, $\mathrm{B}$ in polymerase chain reaction (PCR). Among the factors that complicated the course of the disease, we considered obesity, chronic pathology of the cardiovascular and respiratory systems, diabetes mellitus, immunodeficiency of various etiology and neoplasms.

The diagnosis of pneumonia was established on the basis of a comprehensive analysis of epidemiological and clinical and laboratory data with mandatory X-ray/tomographic confirmation. The course of pneumonia and the need for hospitalization to the intensive care unit was determined on the IDSA/ATS (American Thoracic Society and Infectious Diseases Society of America), wherein we were guided by the order of the Ministry of Health of Ukraine from March 19, 2007 No. 128, and classified the patients into one of five groups, depending on the severity and the presence of concomitant pathology. Treatment of patients with pneumonia I-III group was performed in the diagnostic department of PRCIH; IV - in the intensive care unit. All patients received antiviral therapy (oseltamivir $150 \mathrm{mg}$ /day in the case of pneumonia of II-III group, and $300 \mathrm{mg} /$ day in the case of pneumonia of IV group), antibiotic therapy in accordance with the Protocol of treatment orders of the Ministry of Health of Ukraine from May 20, 2009, No. 189, and from November 18, 2009, No. 832), oxygen therapy for indications.

We have conducted a comprehensive examination of all patients with determination of pulse oxygen saturation $\left(\mathrm{SpO}_{2}\right)$, bacteriological examination of sputum, laboratory and additional tests depending on concomitant and diagnosed pathology with the involvement of consultants of the corresponding profile.

For statistical processing of the research results were used parametric and non-parametric methods of variational statistics. The difference was considered statistically significant at $\mathrm{p}<0.05$.

\section{RESULTS AND DISCUSSION}

The conducted studies showed that 1344 cases of influenza were registered in 2016 according to the official reporting documentation provided by the State Institution "Poltava Regional Laboratory Center of the Ministry of Health of
Ukraine", in Poltava Region, which amounted to 93.91 cases per 100 thousand population, and 305892 cases of acute infections of the upper respiratory tract with multiple or indeterminate localization (21374.46 cases per 100 thousand population). In 2017, the influenza has been diagnosed in 216 patients in the Poltava region ( 15.22 cases per 100 thousand population), and acute infections of the upper respiratory tract with multiple or uncertain localizations have been diagnosed in 232050 patients ( 16353.32 cases per 100 thousand population). In 2018, the diagnosis of "Influenza" was established in 359 patients of Poltava region (25.53 cases per 100 thousand population), and the diagnosis of acute infections of the upper respiratory tract with multiple or uncertain localizations - in 224905 patients (15996,19 cases per 100 thousand population). We also observed a similar tendency to reduce the incidence of influenza in recent years according to the data of PR$\mathrm{CIH}$, as indirectly indicated by the number of hospitalized patients with this pathology. Thus, in 2016, 499 patients were treated in PRCIH with the diagnosis of "Influenza" (65 of them had influenza A, 2 had influenza B, and 432 were diagnosed with influenza clinically with clear clinical and epidemiological data), then in 2017, there were only 104 patients with influenza (influenza A - in 25 patients, influenza B - in 3 patients, influenza (clinically) - in 76 patients), and in 2018 - 187 patients (influenza A - 32, influenza B - 27, influenza (clinically) - 128). It should be noted that the incidence rate has not shown significant growth in recent years, but the frequency of pneumonia, which complicated the influenza according to the PRCIH data, remained at a stable high level (20.84\% in 2016 , $20.19 \%$ in 2017 and $19.7 \%$ in 2018).

Among patients with pneumonia, in a microbiological examination of sputum a pathogenic bacterial agent was identified in $41(43.16 \%)$ patients. We isolated the following microorganisms: S.pneumoniae - 21 patients, S.aureus - 13, Haemophilus influenza - 4 and E.coli - 3 patients.

It should also be noted that in 2 patients we isolated Streptococcus viridans, and in one patient - Staphylococcus epidermidis and in another one - Candida spp. However, according to the literature, the development of bronchopulmonary inflammation for these microorganisms is not characteristic. Their isolation from sputum is likely to indicate the contamination of the material by the flora of the upper respiratory tract, not the etiological significance of these microorganisms.

Most patients with pneumonia as a complication of the influenza $(n=61 ; 64.21 \%)$ were over 40 years of age. However, we have noticed a trend that patients who develop pneumonia caused by S.aureus, were younger - 23 to 49 years (mean age 37,46 $\pm 2,44$ years). Whereas in the group in which we were not able to isolate the bacterial pathogen in sputum, the average age was $49.58 \pm 2.22$ years ( 23 to 80 years), in the group of S.pneumoniae $-57.85 \pm 2.89$ years (28 to 76 years), in the group of Haemophilus influenza $-51.50 \pm 7.45$ years (33 to 69 years) and in the group of E.coli $-48.33 \pm 7.05$ years ( 35 to 59 years).

In general, the risk factors for severe influenza and, 
accordingly, the development of pneumonia were identified with the following frequency: chronic cardiovascular diseases $-42.10 \%(n=40)$, disorders of the respiratory system $-36.84 \%(n=35)$, obesity $-7.37 \%(n=7)$, diabetes mellitus $-8.42 \%(\mathrm{n}=8)$, liver cirrhosis $-2.10 \%(\mathrm{n}=2)$, long smoking period $-41.05 \%(\mathrm{n}=39)$, HIV infection - $1.05 \%(\mathrm{n}=1)$, neoplasms - $2.10 \%(\mathrm{n}=2)$. (Table I). Interestingly, the frequency of identifying risk factors for severe influenza and concomitant pathology was essentially the same when comparing groups with different bacterial agents and the group in which we were not able to isolate the bacterial pathogen in sputum, except that in the group of S.aureus risk factors and concomitant pathology were diagnosed significantly less frequently. This was probably due to the fact that the patients were in the group S.aureus were younger.

The analysis of the time of admission of patients to the hospital showed that early hospitalization prevailed among the patients. This fact indirectly indicated a serious course of the disease and possible early development of complications. Almost half of the patients - $42(44.21 \%)$ were hospitalized for 1-3 days. The bacterial pathogen was not isolated in sputum substantially in all of these patients, which may indicate the primary viral nature of possible complications. Almost the same number of patients ( $\mathrm{n}$ $=47 ; 49.47 \%)$ were hospitalized for $4-6$ days, 6 (6.32\%) patients were hospitalized after 6 days, with no characteristic differences between groups of patients with different bacterial agents in sputum.

At the pre-admission phase, treatment was prescribed to $54(56.84 \%)$ patients: 28 patients received antibacterial therapy drugs, 26 received antiviral therapy drugs, which, as a rule, were combined with symptomatic agents.

In most patients, the disease was characterized by an acute onset with a predominance of symptoms of general toxic syndrome with such frequency: hyperthermia $(\mathrm{n}=$ $94 ; 98.95 \%)$, headache $(\mathrm{n}=65 ; 68.42 \%)$, muscle pain $(\mathrm{n}=$ 37; 38.95\%). Moreover, 11 (11.59\%) patients experienced symptoms of severe toxic syndrome, such as nausea and vomiting. Catarrhal syndrome of varying severity was also observed in the vast majority of patients: scleritis and hyperemia of the oropharyngeal mucosa $(\mathrm{n}=63 ; 66.32 \%)$, dry $(\mathrm{n}=61 ; 64.21 \%)$ and productive $(\mathrm{n}=30 ; 31.58) \%)$ cough. The dry cough changed on productive in most patients in the dynamics $(\mathrm{n}=85 ; 89.47 \%)$. The type of sputum was mucoid $-(\mathrm{n}=60 ; 63.16 \%)$, mucopurulent $-(\mathrm{n}=26 ; 27.37 \%)$ or bloody $-(\mathrm{n}=9 ; 9.47 \%)$. The high incidence of chest pain $(\mathrm{n}=38 ; 40.00 \%)$ and shortness of breath $(\mathrm{n}=32 ; 33.67 \%)$ should be noted. Thus, in general, the clinical course at the onset of the disease was typical substantially in all patients with the prevalence of manifestations of toxic syndrome without differences between groups of patients with different bacterial agents in sputum, except that bloody sputum and severe breathlessness were observed only in groups $S$. pneumoniae $(n=7$ and $n=20$, respectively) or S.aureus ( $n=2$ and $n=12$, respectively) .

Analysis of physical changes in the lungs in hospitalized patients showed that signs of pneumonia (dullness on per- cussion sound over the affected part of the lung, weakened or bronchial breathing, small bubbling rales, crepitations) were determined in almost all patients ( $\mathrm{n}=93 ; 97.89 \%)$.

Of all patients, $10(10.53 \%)$ were assigned to Clinical Group IV, among them unilateral inflammatory process in lungs was observed only in 1 patient (with S.pneumoniae), in the other 9 patients (4 patients with S.pneumoniae, 3 patients with S.aureus and 2 patients without isolated bacterial agent) the inflammation was bilateral. Clinical Group III included 39 (41.05\%) patients: 36 patients had bilateral and 3 patients had unilateral pneumonia. Clinical group II included 46 (48.42\%) patients; all except one had unilateral lung injury.

Radiographic picture of pneumonia in patients had certain features. Unilateral $(\mathrm{n}=49 ; 51.58 \%)$ or bilateral inflammatory process $(\mathrm{n}=46 ; 48.42 \%)$ was recorded essentially with the same frequency. It should be noted that bilateral lesions were mainly observed in patients with S.pneumoniae $(\mathrm{n}=17)$, S.aureus $(\mathrm{n}=11)$, or in a group of patients without bacterial agent $(n=18)$ and assumed primary viral cause of inflammatory changes in the lungs.

However, in case of primary viral interstitial inflammation, we observed a moderate compaction of the lung tissue with signs of diffuse bronchiolitis and bronchopneumonia (a symptom of "ground-glass", "tree-and-bud") with small centrilobular foci without decay and rarely with consolidation phenomena. Whereas, as usually with the addition of the bacterial flora, the inflammatory process began on the periphery and in the lower lobes, first in the form of an increased pulmonary vascularity and inhomogeneous nodular opacity, which later spread in severe cases and formed massive confluent subtotal or total infiltrative changes in the lungs. In some patients, on the background of such massive infiltrative changes, microabscesses were formed in the lung tissue. Interestingly, in all of these patients with abscesses $(n=4)$, we isoleted S.aureus in sputum. The roots of the lungs were substantially expanded and infiltrated. By means of an estimation of the $\mathrm{x}$-ray pattern in the dynamics, it was found that the resorption of infiltrates lasted more than 12 days, and residual pneumonia was preserved in the overwhelming majority $(\mathrm{n}=84 ; 88,42 \%)$ of the persons discharged from the hospital.

The level of $\mathrm{SpO}_{2}$ was significantly differed depending on the prevalence of inflammatory process in the lungs in patients. In patients with pneumonia of Clinical Group II - III, values of $\mathrm{SpO}_{2}$ ranged from $99 \%$ to $91 \%$ (mean $95.1 \pm 0.3 \%)$ without oxygen inhalation. In the case of pneumonia of Clinical Group IV with bilateral lung injury, blood oxygen saturation varied from 92 to $60 \%$ without inhalation of oxygen. Depending on the etiological factor, these were the patients with S.pneumoniae $(\mathrm{n}=5)$, S.aureus $(\mathrm{n}=3)$, or without any bacterial agent $(\mathrm{n}=2)$ with a possible primary viral nature of the disease. All patients with pneumonia of Clinical Group IV received treatment in the intensive care unit to improve the condition from 4 to 14 days (mean $-6.3 \pm 1.2$ days).

In recent years, the scientific literature has reported a severe course severe course and high mortality of pneumonia, 
Table I. Demographic indicators and the frequency of the risk factors of the complicated course of influenza in the examined patients with pneumonia

\begin{tabular}{|c|c|c|c|c|c|c|c|c|c|c|c|c|c|c|c|}
\hline & & \multicolumn{2}{|c|}{ Total } & \multicolumn{2}{|c|}{$\begin{array}{l}\text { No bact. } \\
\text { agent }\end{array}$} & \multicolumn{2}{|c|}{ S.pneumoniae } & \multicolumn{2}{|c|}{ S.aureus } & \multicolumn{2}{|c|}{$\begin{array}{l}\text { Haemophilus } \\
\text { influenza }\end{array}$} & \multicolumn{2}{|c|}{ E.coli } & \multicolumn{2}{|c|}{$\begin{array}{c}\text { Other } \\
\text { pathogens }\end{array}$} \\
\hline & & abs. & $\%$ & abs. & $\%$ & abs. & $\%$ & abs. & $\%$ & abs. & $\%$ & abs. & $\%$ & abs. & $\%$ \\
\hline \multirow{2}{*}{ Gender } & male & 52 & 54.74 & 27 & 54.00 & 12 & 57.14 & 8 & 61.54 & 2 & 50.00 & 2 & 66.67 & 2 & 50.00 \\
\hline & female & 43 & 45.26 & 23 & 46.00 & 9 & 42.86 & 5 & 38.46 & 2 & 50.00 & 1 & 33.33 & 2 & 50.00 \\
\hline \multirow{5}{*}{ Age } & $18-30$ & 16 & 16.84 & 12 & 24.00 & 2 & 9.52 & 2 & 15.38 & - & & - & & - & - \\
\hline & $31-40$ & 18 & 18.95 & 4 & 8.00 & 3 & 14.29 & 8 & 61.54 & 1 & 25.00 & 1 & 33.33 & 1 & 25.00 \\
\hline & $41-50$ & 19 & 20.00 & 7 & 14.00 & 5 & 23,81 & 3 & 23.08 & 1 & 25.00 & 1 & 33.33 & 2 & 50.00 \\
\hline & $51-60$ & 27 & 28.42 & 20 & 40.00 & 4 & 19.05 & - & - & 1 & 25.00 & 1 & 33.33 & 1 & 25.00 \\
\hline & 61 and older & 15 & 15.79 & 7 & 14.00 & 7 & 33.33 & - & - & 1 & 25.00 & - & & - & - \\
\hline \multirow{8}{*}{$\begin{array}{c}\text { Risk } \\
\text { Factors }\end{array}$} & $\begin{array}{l}\text { pathology of } \\
\text { the respiratory } \\
\text { system }\end{array}$ & 35 & 36.84 & 21 & 42.00 & 11 & 52.38 & 1 & $7.69 *$ & 1 & 25.00 & - & - & 1 & 25.00 \\
\hline & $\begin{array}{l}\text { pathology } \\
\text { of the } \\
\text { cardiovascular } \\
\text { system }\end{array}$ & 40 & 42.11 & 23 & 46.00 & 13 & 61.90 & 2 & $15.38^{*}$ & 1 & 25.00 & 1 & 33.33 & - & - \\
\hline & obesity & 7 & 7.37 & 5 & 10.00 & 2 & 9.52 & - & - & - & & - & & - & - \\
\hline & $\begin{array}{l}\text { diabetes } \\
\text { mellitus }\end{array}$ & 8 & 8.42 & 5 & 10.00 & 2 & 9.52 & - & - & - & & - & & 1 & 25.00 \\
\hline & $\begin{array}{l}\text { hepatic } \\
\text { cirrhosis }\end{array}$ & 2 & 2.11 & 1 & 2.00 & 1 & 4.76 & - & - & - & & & & - & \\
\hline & smoking & 39 & 41.05 & 16 & 32.00 & 11 & 52.38 & 7 & 53.85 & 2 & 50.00 & 1 & 33.33 & 2 & 50.00 \\
\hline & HIV infection & 1 & 1.05 & 1 & 2.00 & - & - & - & - & - & & - & & - & - \\
\hline & $\begin{array}{l}\text { malignant } \\
\text { neoplasms }\end{array}$ & 2 & 2.11 & 1 & 2.00 & 1 & 4.76 & - & - & - & & - & & - & - \\
\hline
\end{tabular}

Note. Percentages were calculated from the number of patients in the appropriate group, depending on the etiologic agent

* - significant difference compared to the patients in the group S.pneumoniae and group without bacterial agent $(p<0.05)$

which is caused by a combination of S.aureusand influenza virus. This fact is associated with a powerful role of staphylococcus virulence factors in the pathogenesis: Panton-Valentine leukocidin, phenol-soluble modulin al (PSMa1) and -3 (PSMa3), $\alpha$-hemolysin (Hla), etc. $[8,9,10,11]$. We have identified an association S.aureus and influenza virus in $13(13.68 \%)$ patients. The clinical symptomatology of pneumonia in these individuals was mainly characterized by a severe course, despite the relatively young age of the patients. Almost every fourth of these patients (3 out of 13) was assigned to Clinical Group IV. Moreover, vast majority of patients with S.aureus was characterized by bilateral subtotal or total lung injury (11 of 13).

In the course of our research we aimed to analyze the epidemiological data and clinical course of pneumonia as a complication of influenza in the Poltava region, depending on the etiological factor. We have received original data for our region and consider that the results of our research can be extrapolated to the whole country, taking into account the geographical and socio-economic situation of the region. On the other hand, this may be an insignificant methodological limitation of the results obtained. However, the above data confirm the trends discribed in the literature that require further research to optimize the diagnostic and therapeutic tactics of pneumonia which complicate influenza, depending on their etiological agent.

\section{CONCLUSIONS}

Studies have shown that despite a decrease in the incidence of influenza in recent years, the incidence of pneumonia, which complicated the course of influenza, remained consistently high $(19.7 \%-20.8 \%)$ with bacteriological isolation of S.pneumoniae (22.11\%), S.aureus (13.68\%), Haemophilus influenza (4.21\%) and E.coli (3.16\%). Severe course of pneumonia with bloody sputum, evident shortness of breath, bilateral lung damage, and need for oxygen support were significantly more frequently reported in patients with isolated S.pneumoniae and S.aureus. However, the severe course of the disease with the formation of abscesses in the lungs was observed only in the group S.aureus despite the relatively young age of such patients and significantly fewer risk factors for severe influenza and comorbidities. 


\section{REFERENCES}

1. Mironenko A.P., Holubka 0.S., Onyshchenko 0.V. et al. Hryp v Ukrayini v epidemichnomu sezoni 2015-2016 rr. ta prohnoz na nastupnyy sezon 2016-2017 rr. [Klinichna imunolohiya. Alerholohiya. Infektolohiya]. 2016; 4 (93): 6-9 (In Ukrainian).

2. Dzyublyk Y.0., Solovyov S.0., Dzyublyk I.V. Hryp i pnevmoniya: yak vony pov"yazani?. [Zdorov"ya suspil'stva]. 2013; 1: $52-56$ (In Ukrainian).

3. Pryymenko N.0. Osoblyvosti klinichnoho perebihu pnevmoniy, yaki uskladnyuvaly hryp A/H1N1 v epidemichnomu sezoni 2009-2010 rr. v Poltavs'kiy oblasti. [Aktual'ni problemy suchasnoyi medytsyny: Visnyk ukrayins'koyi medychnoyi stomatolohichnoyi akademiyi]. 2012; T. 12, № 1-2 (37-38): 144-148 (In Ukrainian).

4. Dubyns'ka H.M., Pryymenko N.0., Bodnar V.A. Hryp u doroslykh [navchal'nyy posibnyk]. 2018; 137 (In Ukrainian).

5. Vozianova Z.I., Golubovskaya 0.A. Pandemiya grippa A/H1N1: osobennosti techeniya i nesostoyavshiyesya. 2010; 2: 4-11 (In Russian).

6. Katsurada N. The impact of virus infections on pneumonia mortality is complex in adults: a prospective multicentre observational study. BMCInfectDis. 2017;Dec 6;17(1):755. doi: 10.1186/s12879-017-2858-y.

7. Malosh R.E., Martin E.T., Ortiz J.R. et al. The risk of lower respiratory tract infection following influenza virus infection: A systematic and narrative review .Vaccine. 2018; Jan 2;36(1):141-147. doi: 10.1016/j. vaccine.2017.11.018.

8. Mulcahy M.E., McLoughlin R.M. Staphylococcus aureus and Influenza A Virus: Partners in Coinfection. MBio. 2016; Dec 13;7(6). pii: e02068-16. doi: 10.1128/mBio.02068-16.

9. Wuerth B.A., Bonnewell J.P., Wiemken T.L. et al. Trends in Pneumonia Mortality Rates and Hospitalizations by Organism, United States, 2002-2011(1). Emerg Infect Dis. 2016; Sep;22(9):1624-7. doi: 10.3201/eid2209.150680.

10. Löffler B., Niemann S., Ehrhardt C. et al. Pathogenesis of Staphylococcus aureus necrotizing pneumonia: the role of PVL and an influenza coinfection. Expert Rev Anti Infect Ther. 2013; 0ct;11(10):1041-51. doi: 10.1586/14787210.2013.827891. Epub 2013 Sep 27.

11. Jeannoel M., Casalegno J.S., Ottmann M. et al. Synergistic Effects of Influenza and Staphylococcus aureus Toxins on Inflammation Activation and Cytotoxicity in Human Monocytic Cell Lines. Toxins (Basel). 2018; Jul 11;10(7). pii: E286. doi: 10.3390/toxins10070286.
This study was carried out as part of the research work "Optimization of treatment and diagnostic tactics for infectious diseases of viral, bacterial, parasitic etiology and their mixed forms based on the study of their clinical and pathogenetic features" of the Department of Infectious Diseases with Epidemiology, Ukrainian Medical Stomatological Academy. State Registration No. 0119 U102923.

\section{ORCID and contributionship:}

Vadym A. Bodnar: 0000-0002-1277-9344 ${ }^{A, B, D}$

Tetiana I. Koval: 0000-0003-2685-8665 ${ }^{F}$

Nataliia O. Pryimenko: 0000-0002-8265-1143 C,D

Galyna M. Dubyns'ka: 0000-0003-0950-8997 ${ }^{E}$

Tetiana M. Kotelevska: 0000-0001-7508-4876 ${ }^{B}$

Nina P. Lymarenko: 0000-0002-9858-8740 ${ }^{B}$

Liudmyla M. Syzova: 0000-0002-8335-3295 ${ }^{B}$

Lesia A. Bodnar: 0000-0002-0032-8853 ${ }^{B}$

\section{Conflict of interest:}

The Authors declare no conflict of interest.

\section{CORRESPONDING AUTHOR Vadym A. Bodnar \\ Ukrainian Medical Stomatological Academy \\ 23 Shevchenka st., 36011 Poltava, Ukraine \\ tel: +380677879510 \\ e-mail:bodnar.vadym@gmail.com}

Received: 09.10.2019

Accepted: 10.04 .2020

A - Work concept and design, B - Data collection and analysis, C - Responsibility for statistical analysis, D-Writing the article, $\mathbf{E}$-Critical review, F- Final approval of the article 